\title{
Dopamine and Mushroom Bodies in Drosophila: Experience-Dependent and -Independent Aspects of Sexual Behavior
}

\author{
Wendi S. Neckameyer \\ Department of Pharmacological and Physiological Science \\ Saint Louis University School of Medicine \\ St. Louis, Missouri 63104 USA
}

\begin{abstract}
Depletion of dopamine in Drosophila melanogaster adult males, accomplished through systemic introduction of the tyrosine hydroxylase inhibitor 3-iodo-tyrosine, severely impaired the ability of these flies to modify their courtship responses to immature males. Mature males, when first exposed to immature males, will perform courtship rituals; the intensity and duration of this behavior rapidly diminshes with time. Dopamine is also required for normal female sexual receptivity; dopamine-depleted females show increased latency to copulation. One kilobase of $5^{\prime}$ upstream information from the Drosophila tyrosine hydroxylase (DTH) gene, when fused to the Escherichia coli $\beta$-galactosidase reporter and transduced into the genome of Drosophila melanogaster, is capable of directing expression of the reporter gene in the mushroom bodies, which are believed to mediate learning acquisition and memory retention in flies. Ablation of mushroom bodies by treatment of newly hatched larva with hydroxyurea resulted in the inability of treated mature adult males to cease courtship when placed with untreated immature males. However, functional mushroom bodies were not required for the dopaminergic modulation of an innate behavior, female sexual receptivity. These data suggest that dopamine acts as a signaling molecule within the mushroom bodies to mediate a simple form of learning.
\end{abstract}

\section{Introduction}

Catecholamines act as transmitters in the nervous systems of both vertebrates and invertebrates; several pharmacological studies in mammalian systems have implicated catecholamines in synaptic modulation and behavioral plasticity (Civelli et al. 1993; Saw aguchi and Goldman-Rakic 1994). Perturbation of catecholaminergic systems has also been implicated in the etiology of schizophrenia and depression (Hornykiewicz 1966; Goldstein and Deutch 1992; Seeman et al. 1993), suggesting that catecholamines play a role in the modulation of cognitive function.

Tyrosine hydroxylase, the first and rate-limiting enzyme in the synthesis of catecholamines, is highly conserved among evolutionarily diverged species. Drosophila tyrosine hydroxylase (DTH) shares $50 \%$ amino acid identity with its mammalian counterparts, and its biochemical and regulatory mechanisms are also highly conserved (Neckameyer and Quinn 1989; W. Neckameyer, unpubl.). Depletion of dopamine levels in larval and adult stages by systemic administration of tyrosine hydroxylase inhibitors has proven to be a useful pharmacological approach to elucidate the physiological requirements for dopamine.

Recently, we have demonstrated that dopamine modulates female sexual receptivity in Drosophila melanogaster (Neckameyer 1998). This role for dopamine also appears to be utilized in mammalian systems (Mani et al. 1994). Exposure to male courtship stimulates a suitable female to accept the male's overtures (Tompkins et al. 1982); how ever, this is not considered a learned behavior.

One study has suggested that in Drosophila, as in mammals, biogenic monoamines may play a role

LEARN IN G \& MEM ORY 5:157-165 @ 1998 by Cold Spring Harbor Laboratory Press ISSN 1072-0502/98 \$5.00

$$
\begin{array}{lllllllllllllll}
L & E & A & R & N & I & N & G & \underset{\mathbf{1 5 7}}{\boldsymbol{X}} & M & E & M & O & R & Y
\end{array}
$$


in learning (Tempel et al. 1984), but this work has not yet been replicated. Using a pharmacological approach to deplete dopamine levels in adult males, it has been demonstrated here that dopamine is required for normal habituation in an experience-dependent courtship paradigm and that the focus for this dopaminergic modulation of one type of learning likely resides within the mushroom bodies. Female sexual receptivity, which does not require learning, also does not require functional mushroom bodies.

\section{Materials and Methods}

\section{FLY CULTURE AND COURTSHIP ANALYSIS}

Unless otherwise specified, wild-type Canton-S flies were maintained in individual pint bottles containing standard agar-cornmeal-molasses food at $25^{\circ} \mathrm{C}$ on a 12 -hr light-dark cycle. Newly eclosed males were placed singly in vials containing filter discs saturated with $2 \%$ yeast- $5 \%$ sucrose or yeastsucrose plus $10 \mathrm{mg} / \mathrm{ml}$ 3-iodo-tyrosine (3/Y), or yeast-sucrose plus $10 \mathrm{mg} / \mathrm{ml} 3 \mathrm{IY}$ and $10 \mathrm{mg} / \mathrm{ml}$ L-3,4-dihydroxyphenylalanine (LDOPA). Treatment with this concentration of inhibitor has previously been show $n$ to substantially deplete dopamine levels in adult flies (Neckameyer 1996). After 4-6 days, each male was placed with a newly eclosed (0-3-hr-old) male fly and observed in a 10-position mating chamber wheel for 30 min. The courtship paradigm has been described previously (Gailey et al. 1986; for review, see Greenspan 1995), as has the conditioned response to immature males (Gailey et al. 1982). Courtship indices (Cls) were collected as described in Gailey et al. (1986; see also Siegel and Hall 1979) for the first and last $10 \mathrm{~min}$ utes of the 30 -min observation period.

\section{GENERATION OF TRANSGENIC LINES}

A 1-kb genomic fragment from the DTH gene (Neckameyer and White 1993), consisting of $\sim 800$ bp of promoter sequences adjacent to the first 200 bp of DTH $5^{\prime}$-untranslated sequences was ligated into the the unique BamHI site of the pJY505 CaSpeR transformation vector (gift of Dr. Jerry Y in) in both the $5^{\prime}$ to $3^{\prime}$ (p1.2DTHlacZ) and $3^{\prime}$ to $5^{\prime}$ (p1.2'DTHlacZ) orientations. pJY505 is a derivative of CaSpeRhs43 $\beta$ gal, which includes a truncated hs43 promoter and the E coli $\beta$-galactosidase gene dow nstream of a multiple cloning region (Yin et al. 1994). Details of the cloning and generation of transgenic lines will be presented elsew here $(W$. Neckameyer, A. Mayer, and M. Van Kanegan, in prep.). Cesium chloride-banded plasmid DNA (500 $\mu \mathrm{g} / \mathrm{ml}$ ) was injected into a $\mathrm{w}^{-}$strain (Rubin and Spradling 1982) with the $\mathrm{p} \pi 25.7 \mathrm{wc}$ turbo plasmid $(100 \mu \mathrm{g} / \mathrm{ml})$ as the source of transposase (Robertson et al. 1988).

Single transformant lines for both the $3^{\prime}$ to $5^{\prime}$ (p1.2'DTHlacZ) and the $5^{\prime}$ to $3^{\prime}$ (p1.2DTHlacZ) orientations of the DTH promoter sequence were generated; the p1.2'DTHlacZ stock, when homozygous, exhibited a strong red eye color. The p1.2DTHlacZ stock, when homozygous, exhibited a light apricot eye color. Two other independent lines were isolated from the latter stock by use of a genetic strain carrying a source of transposase to jump the transgene, $1 \mathrm{~F}-4$ and $2 \mathrm{M}-1$, which exhibited orange and red eye colors, respectively.

\section{STAINING FOR $\beta$-GALACTOSIDASE}

Third instar larval and 1-day-old adult brain tissues were dissected from control (Df[1]w and p1.2'DTHlacZ) and experimental (p1.2DTHlacZ series) lines. The staining protocol was as follows: Tissues were dissected in PBS and immediately fixed for $5 \mathrm{~min}$ in $5 \%$ formaldehyde/ $1 \times$ PBS. Tissues were washed $4 \times$ for 5 min in $1 \times$ PBS, and incubated overnight at $37^{\circ} \mathrm{C}$ in a moist chamber in assay buffer [3.1 mM K ${ }_{3} \mathrm{Fe}(\mathrm{CN})_{6} / 3.1 \mathrm{~mm} \mathrm{~K}{ }_{4} \mathrm{Fe}$ $(\mathrm{CN})_{6} / 0.15 \mathrm{M} \mathrm{NaCl} / 1 \mathrm{~mm} \mathrm{MgCl}_{2} / 10 \%$ DMSO/10 $\mathrm{mm} \mathrm{NaP}_{\mathrm{i}}(\mathrm{pH}$ 6.8)/0.1\% 5-bromo-4-chloro-3-indolyl$\beta$-D-galactoside]. Samples were postfixed by washing $4 \times$ for 5 min in $1 \times$ PBS, fixing in $5 \%$ formaldehyde, $1 \times$ PBS for $2 \mathrm{hr}$, followed by four 5-min washes in $1 \times$ PBS. Tissues were prepared for mounting by incubation for at least $20 \mathrm{~min}$ in a $30 \%-50 \%-90 \%$ glycerol series in $1 \times$ PBS and were mounted in $90 \%$ glycerol/1 $1 \times$ PBS on glass slides.

\section{ABLATION OF MUSHROOM BODIES WITH HYDROXYUREA}

Several hundred Canton-S adult flies were maintained for 1 week in a population cage kept at $25^{\circ} \mathrm{C}$ on a 12 -hr light-dark cycle. Flies were allow ed to lay eggs for 1-1.5 hr on apple juice-agar plates, and any larvae that had hatched were removed after $20 \mathrm{hr}$. Newly hatched larvae were then collected within a 45 -min period and placed on $60-\mathrm{mm}$ petri dishes containing apple juice-agar and either a small amount of yeast paste ( 0.5 grams of baker's yeast in $1 \mathrm{ml}$ of $\mathrm{H}_{2} \mathrm{O}$ ), or yeast paste with

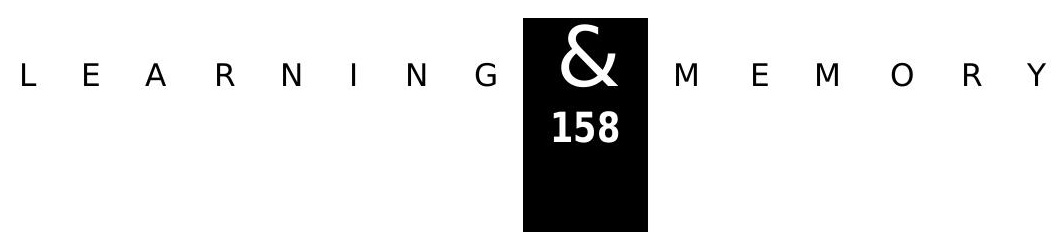


$50 \mathrm{mg} / \mathrm{ml}$ hydroxyurea (de Belle and Heisenberg 1994) for $4 \mathrm{hr}$ at $25^{\circ} \mathrm{C}$. The larvae were harvested and placed in vials containing $5 \mathrm{ml}$ of $2 \%$ baker's yeast, $5 \%$ yeast extract, $5 \%$ sucrose, $0.8 \%$ agar, and $0.5 \%$ 9:1 propionic acid/phosphoric acid. The vials were maintained at $25^{\circ} \mathrm{C}$ on a 12 -hr light-dark cycle until eclosion, when male flies were placed singly in vials containing standard agar-cornmealmolasses food, and maintained under these conditions for 4- 6 days before behavioral analysis. A smaller cage containing the p1.2DTHlacZ transgenic strain 2M-1 was run in parallel; larval brains were dissected from the wandering third instar stage and stained as described above.

\section{COURTSHIP ANALYSIS FOR FEMALE RECEPTIVITY}

One to five newly eclosed females, treated with yeast paste or yeast paste plus hydroxyurea, as described above, were maintained in vials containing standard fly food medium for 4-6 days. A single female was placed with a 4- to 6-day-old virgin untreated Canton-S male fly and observed in a 10-position mating chamber wheel until copulation occurred. Elapsed time to copulation and male $\mathrm{Cl}$ were determined for each pair of animals (Neckameyer 1998).

\section{STATISTICAL ANALYSIS}

Statistical analysis was accomplished by use of the JMP statistics softw are program for Macintosh. $\mathrm{Cls}$ for the dopamine-depletion and rescue studies (Fig. 1) were subjected to arcsine square root transformations to approximate normal distributions before performing statistical analysis (Sokal and Rohlf 1995). Then, two-w ay analyses of variance (ANOVAs) were performed (see legend to Fig. 1). For the hydroxyurea ablation studies (see Fig. 4, below), a Shapiro-Wilk $W$ test was performed to demonstrate that the Cls were normally distributed (normal distribution at 0.05 level; $\mathrm{P}=0.057$ ). Then, $\mathrm{a}$ two-way ANOVA followed by planned pairwise comparisons was performed (see legend to Fig. 4, below). Critical $\mathrm{P}$ values were adjusted according to Sokal and Rohlf (1995).

\section{Results}

\section{DOPAMINE-DEPLETED MALES DO NOT LEARN IN A CONDITIONED COURTSHIP ASSAY}

Depletion of dopamine in D. melanogaster

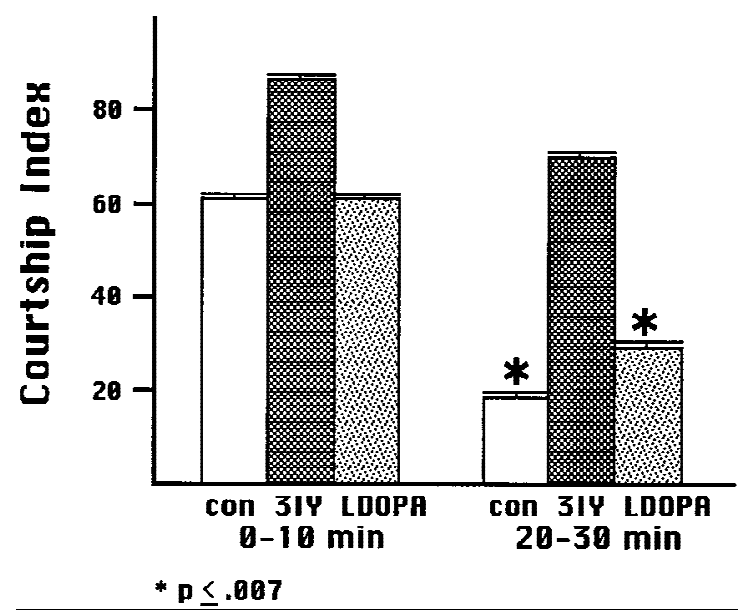

Figure 1: Dopamine-depleted males do not learn in a conditioned courtship assay. Canton-S males were collected within $1 \mathrm{hr}$ of eclosion and maintained singly in vials. All animals were 4-5 days old when tested. (con) Control animals fed $2 \%$ yeast- $5 \%$ sucrose $(n=15)$; (3IY) animals fed yeast-sucrose containing $10 \mathrm{mg} / \mathrm{ml} 3 \mathrm{IY}$ ( $n=18$ ); (LDO PA) animals fed yeast-sucrose containing $10 \mathrm{mg} / \mathrm{ml}$ 3IY plus $10 \mathrm{mg} / \mathrm{ml}$ L-3,4-dihydroxyphenylalanine $(n=15)$. A two-way ANOVA was applied using arcsine transformed $\mathrm{Cls}$ with genotype (control, DA-depleted, rescued) and habituation $\left(\mathrm{Cl}_{1}\right.$ vs. $\left.\mathrm{Cl}_{2}\right)$ as the main effects. The planned comparisons are as follows (adjusted $\alpha=0.017$ ): con $_{1}$ vs. con $_{2}, P=0.00001 ; 3 \mathrm{IY}_{1}$ vs. $3 \mathrm{IY}_{2}, P=0.18$; LDOPA 1 Vs. LDOPA $2, P=0.0016$. Bars above the column denote standard error of the mean. $(*)$ $P \leqslant 0.002\left(\mathrm{Cl}_{1}\right.$ vs. $\left.\mathrm{Cl}_{2}\right)$.

adult males, accomplished by systemic introduction of the tyrosine hydroxylase inhibitor 3IY, perturbed their ability to alter their courtship behavior when exposed to newly eclosed males (Fig. 1). This response was specific as dopamine depletion does not affect the male's courtship behavior with a virgin female (Neckameyer 1998), nor does it induce homosexual behavior with mature males (M. Walzer and W. Neckameyer, unpubl.).

Immature male Drosophila elicit the same courtship behaviors from mature males as do virgin females, but the intensity of this courtship diminishes rapidly over time. The mature male's experiences with the immature male result in a distinct alteration in courtship response, which is thus considered an experience-dependent courtship modification (EDCM; see Tompkins 1989). Gailey et al. (1982) demonstrated that during the first 10 min of observation, normal male D. melanogaster spent $67 \%$ of the time engaged in active courtship of an immature male $(\mathrm{Cl}=67)$, but the $\mathrm{Cl}$ dropped to 17 during the last $10 \mathrm{~min}$ of the 30 -min observation 
period. In the experiments presented here, male Drosophila fed yeast-sucrose as adults displayed Cls during the first and subsequent observation periods that were similar (Fig. 1) to those reported by Gailey et al. (1982), indicating that yeast-sucrose fed males significantly diminished their courtship of immature males $(\mathrm{P}=0.00001)$. How ever, males given yeast-sucrose containing 3IY to deplete dopamine levels show ed perturbations in this habituation paradigm: These males courted vigorously in the first $10 \mathrm{~min}$ and did not significantly decrease this behavior over time. This effect was rescuable by the addition of LDOPA to food containing the tyrosine hydroxylase inhibitor, demonstrating that the perturbation in learning in this paradigm is modulated by dopamine.

The initial courtship of immature males by dopamine-depleted males was significantly higher than that of controls (one way ANOVA, Dunn's t test, $\mathrm{P}<0.005$, Fig. 1), apparently because normal males begin to habituate within the first $10 \mathrm{~min}$ of the observation period. This effect is also rescuable by treatment with LDOPA in addition to the tyrosine hydroxylase inhibitor, as $\mathrm{Cls}$ for the initial observation period for 3IY + LDOPA-treated animals is not significantly different from that of controls.

\section{THE CORE DTH PROMOTER DRIVES REPORTER EXPRESSION IN THE MUSHROOM BODIES}

To identify the temporal and spatial developmental requirements for dopamine, the DTH promoter was fused to a reporter gene, and this construct was transduced into the genome of Drosophila. Staining patterns revealed that this promoter could drive expression of the reporter in mushroom body tissue in both larval and adult brains (Fig. 2); in addition, staining was detected, as expected, in embryonic tissues, gonads, and cuticle (data not shown).

DTH is encoded by the pale (ple) locus (Neckameyer and White 1993); all know $n$ alleles of ple are embryonic lethals, presumably a reflection of the vital role for dopamine in development (Neckameyer 1996). Reintegration of $8 \mathrm{~kb}$ of genomic DNA from the DTH locus, which included only $1 \mathrm{~kb}$ of $5^{\prime}$ upstream information, was sufficient to rescue the ple mutation from embryonic lethality to adult viability. Morphological and immunocytochemical characterization of the transgenic lines suggested that these sequences represented the core promoter, capable of directing correct temporal and spatial expression of DTH,

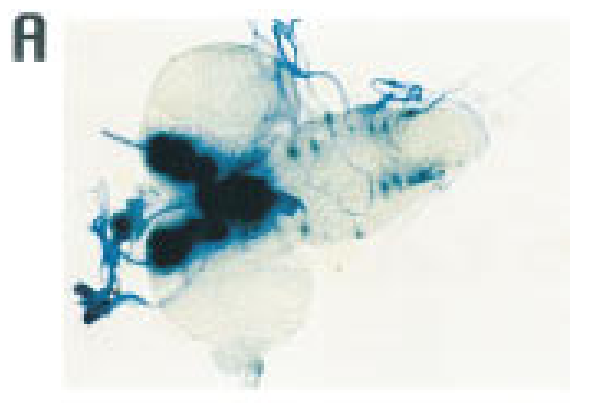

B

Figure 2: The core DTH promoter drives reporter expression in the mushroom bodies. (A) $\beta$-Galactosidase staining of brain tissue from a wandering third instar larva. (B) $\beta$-Galactosidase staining of brain from a 1-dayold adult male. Both tissues were dissected from the $2 \mathrm{M}-1$ transgenic line. Controls (Df[1]w, no transgene; p1.2'DTHlacZ, DTH promoter in $3^{\prime} \rightarrow 5^{\prime}$ orientation) show no staining (data not shown).

although likely lacking all sequences necessary for quantitative expression, as the percentage of adult rescue was less than expected (Neckameyer and White 1993). Fusion of sequences containing the DTH core promoter to the Escherichia ooli $\beta$-galactosidase reporter gene demonstrated expression in the mushroom bodies in the transgenic lines; the most strongly expressing line, $2 \mathrm{M}-1$, showed intense staining of mushroom bodies in third instar larval brain lobes (Fig. 2A), and occasional staining in the adult brain (Fig. 2B). Staining in adult tissues was restricted to the calyx (Fig. 2B), which is likely to be the site of processing of chemosensory information (de Belle and Heisenberg 1994). The transgenic lines also expressed the reporter transgene in the expected pattern of dopaminergic neurons at the larval stage (Fig. 2A).

\section{MALES WITH ABLATED MUSHROOM BODIES DO NOT LEARN IN AN EXPERIENCE-DEPENDENT MODIFICATION OF BEHAVIOR ASSAY}

The mushroom bodies have been shown to mediate associative odor learning in Drosophila

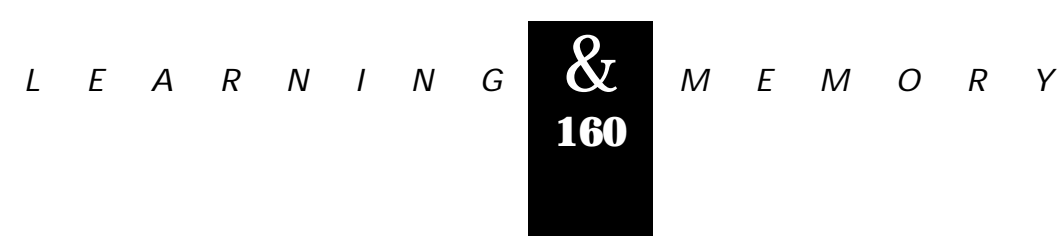


(de Belle and Heisenberg 1994, 1996; Connolly et al. 1996). Given the expression of the DTH promoter in this tissue and the demonstration that dopamine is required for an experience-dependent modification of male courtship behavior in Drosophila, we examined whether ablation of the mushroom bodies would also result in a male's inability to cease courtship of an immature male. The $2 \mathrm{M}-1$ transgenic line was treated in parallel, and dissection of third instar larval brains from control (Fig. 3A) larvae showed the expected staining in the mushroom bodies. The hydroxyurea-treated animals showed an overall decrease in mushroom body staining (Fig. 3B), and, in some cases, perturbations in mushroom body structure, indicating that the treatment was successful in ablating mushroom body tissue. The staining procedure for lacZ transgenic strains is not quantitative, and under some circumstances, normal brain tissues from the p1.2DTHlacZ transgenic lines do not stain. Therefore, a lack of staining might not necessarily indicate complete ablation of the mushroom bodies. However, $\sim 3 / 4$ of the brain tissues that did stain from hyroxyurea-treated animals (pooled from six independent experiments) showed substantially
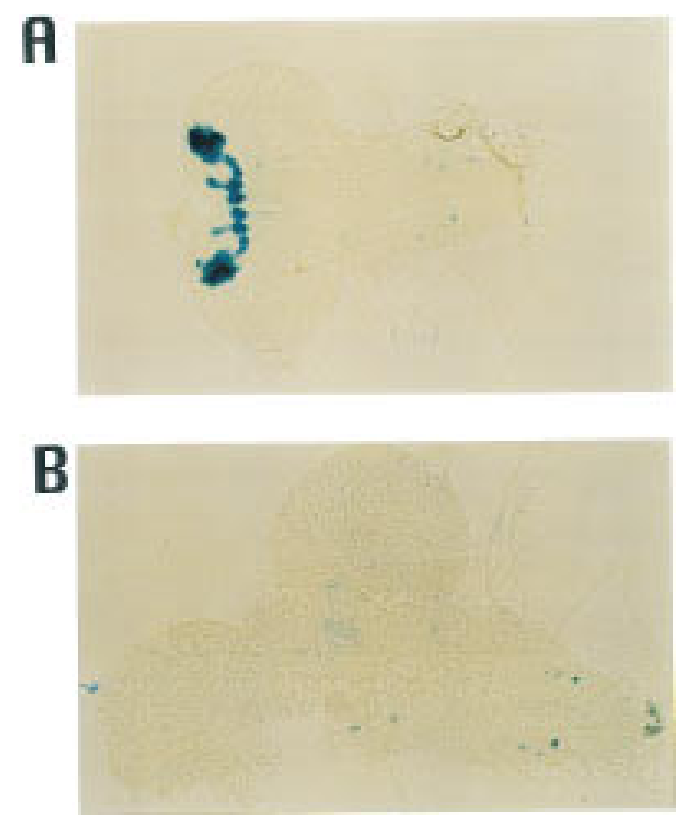

Figure 3: Treatment with hydroxyurea results in diminished staining of the mushroom bodies in the DTH-lacZ transgenic strain 2M-1. (A) Larval brain dissected from a third instar treated with yeast paste for $4 \mathrm{hr}$ within $1 \mathrm{hr}$ after hatching. $(B)$ Larval brain dissected from a third instar treated with $50 \mathrm{mg} / \mathrm{ml}$ hydroxyurea in yeast paste for $4 \mathrm{hr}$ within $1 \mathrm{hr}$ after hatching.

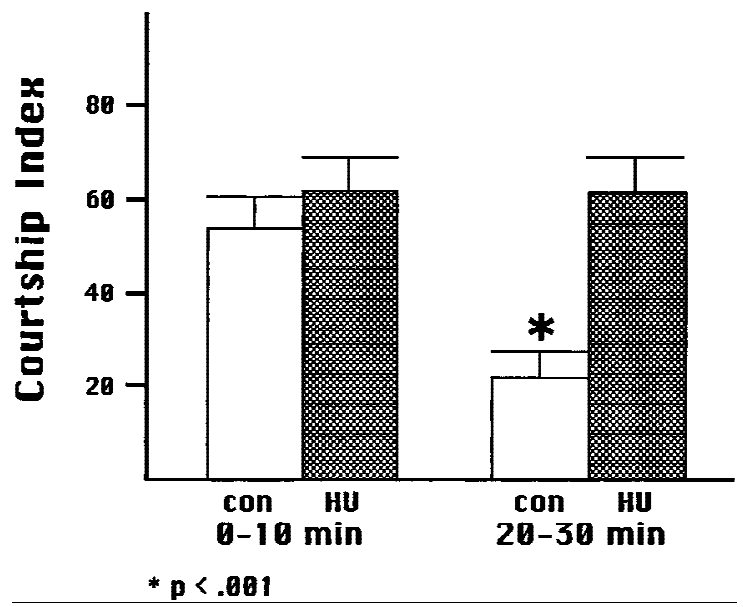

Figure 4: $\quad$ Males with ablated mushroom bodies do not learn in a conditioned courtship assay. (con) Larvae 0-1 $\mathrm{hr}$ old treated for $4 \mathrm{hr}$ with yeast paste and tested as 4 - to 6-day-old adults $(n=12)$; ( HU) larvae 0 - to 1-hr-old treated for $4 \mathrm{hr}$ with $50 \mathrm{mg} / \mathrm{ml}$ hydroxyurea in yeast paste and tested as 4 - to 6 -day-old adults $(n=13)$. Results pooled from four independent experiments. Cls were tested for normality and were normally distributed. A two-way ANOVA was then applied with genotype (control, HU) and habituation as the main effects. This was followed by a planned pairwise comparison (adjusted $\alpha=0.007$ ): con $_{1}$ vs. $\mathrm{HU}_{1}, P=0.29$; $\mathrm{con}_{1}$ vs. $\mathrm{Con}_{2}, P=0.0002, \mathrm{HU}_{1}$ vs. $\mathrm{HU}_{2}, P=0.90$. Bars above the columns denote standard error of the mean. $(*)$ $P=0.0002\left(\mathrm{Cl}_{1}\right.$ vs. $\left.\mathrm{Cl}_{2}\right)$.

diminished staining in the region of the mushroom bodies.

Adult males with undeveloped mushroom bodies, having been treated with hydroxyurea for the first $4 \mathrm{hr}$ of the larval stage, also failed to habituate in the EDCM learning paradigm (Fig. 4): No decrease in courtship of untreated immature males by treated mature males was seen. However, control males, treated exactly the same but without the addition of hydroxyurea to their food, behaved normally, and significantly decreased their courtship of immature males in the latter part of the observation period $(\mathrm{P}<0.0002)$. These data provide further evidence that the mushroom bodies in Drosophila mediate the processes of learning, and, more specifically, mediate the processes of habituation as well as those of associative learning.

\section{FEMALE SEXUAL RECEPTIVITY IS UNAFFECTED BY MUSHROOM BODY ABLATION}

Although dopamine is apparently required for

\section{$\begin{array}{llllllllllllllll}L & E & A & R & N & I & N & G & \underset{\mathbf{1 6 1}}{\mathbf{X}} & M & E & M & O & R & Y\end{array}$}


the female's reception and/or processing of the male's chemosensory courtship cues, ablation of the mushroom bodies does not result in perturbed female sexual receptivity (Table 1). Four- to sixday-old Drosophila females, collected within a few hours of eclosion and treated with $10 \mathrm{mg} / \mathrm{ml}$ of the tyrosine hydroxylase inhibitor 3IY, are significantly less sexually receptive to mature males, as judged by latency to copulation (Neckameyer 1998). Their behavior resembles that of immature virgin females in that males will court them vigorously even though the dopamine-depleted females may reject the courting attempts. This reduction in mating latency is not attributable to disinterest by the male or perturbations in locomotor activity of the female. The treated females elicit normal courtship behaviors from the male, and, in this respect, are indistinguishable from untreated females; however, they do not respond appropriately to the male's courtship cues (Neckameyer 1998). Previous studies have genetically mapped a focus within head tissue for normal female sexual receptivity (Tompkins and Hall 1983). Latency to copulation and male $\mathrm{Cls}$ for females treated as larvae to ablate the mushroom bodies are indistinguishable from those of control animals (Table 1). Thus, a behavior mediated by dopamine which is experience-dependent but which does not require learning, also does not require functional mushroom bodies.

\section{Discussion}

The experience-dependent courtship paradigm represents a habituative learning process, as there is a distinct decrease in courtship behavior to the given stimulus (Gailey et al. 1982). Normal ma-

Table 1: Female sexual receptivity is unaffected by mushroom body ablation

\begin{tabular}{lcc}
\hline & $\begin{array}{c}\text { Time to } \\
\text { copulation (min) }\end{array}$ & $\begin{array}{c}\text { Courtship } \\
\text { index }\end{array}$ \\
\hline Control & 4.9 & 60.0 \\
HU & 4.8 & 68.9 \\
\hline
\end{tabular}

Larvae were treated as 0 - to 1-hr-old larvae for $4 \mathrm{hr}$ with $50 \mathrm{mg} / \mathrm{ml}$ yeast paste and tested as 4 - to 6 -day-old adults; controls were treated in parallel and fed yeast paste alone. Virgins were collected within $1 \mathrm{hr}$ of eclosion and maintained in vials with standard food and one to five females per vial. Results pooled from five independent experiments. $n=8$ for both controls and hydroxyurea (HU)-treated animals. ture males gradually become unresponsive to the attractive sex pheromones synthesized by immature males (Vaias et al. 1993); the data presented here suggest the pheromones cease having an excitatory effect because of specific changes within the central nervous system, rather than because pheromonal receptors stop responding. The dopamine-depleted males obviously perceive the stimuli, as they respond to this cue by initiating a vigorous courtship, which actually exceeds that of control males (Fig. 1).

Dopamine, and its biosynthetic enzyme tyrosine hydroxylase, are found in multiple tissues throughout development, and are required for signal transduction in both neuronal and non-neuronal pathways (Neckameyer 1996). The data presented here suggest a focus within the mushroom bodies for a dopaminergic-modulated learning. Treatment with hydroxyurea dramatically reduces (or abolishes) calyx volume in the mushroom bodies, and there is a strong correlation betw een calyx size and odor learning (de Belle and Heisenberg 1994). Our finding that the DTH core promoter drives expression of a reporter gene within the calyces of the adult brain (Fig. 2B) provides evidence that the focus for dopaminergic modulation of the habituation response resides within the mushroom bodies. The weaker expression in adult brain tissue relative to larval is consistent with the weaker adult transgenic rescue observed with the core DTH promoter (Neckameyer and White 1993). Reporter constructs containing additional 5' DTH upstream sequences (which direct significantly greater adult rescue; W. Neckameyer, unpubl.) have been generated to determine whether DTH is expressed solely within the calyces or within additional mushroom body regions.

Treatment with hydroxyurea during the first 4 $\mathrm{hr}$ of larval life also results in specific structural changes within the antennal lobe (Stocker et al. 1996); how ever, there is no tyrosine hydroxylase nor catecholamine immunoreactivity found in antennal lobe tissue (Budnik and White 1988; Nassel and Elekes 1991). In addition, several genes comprising part of an adenylate cyclase- $G$ protein signaling pathway are expressed within mushroom body tissue, including a dopamine receptor (Feng et al. 1996; Han et al. 1996). Dopamine is believed to act through a $\mathrm{G}$ protein-coupled membrane receptor (Jackson and Westlind-Danielsson 1994); the data presented here are consistent with the hypothesis that dopamine activates a cAMP-mediated signaling pathway within the mushroom bod-

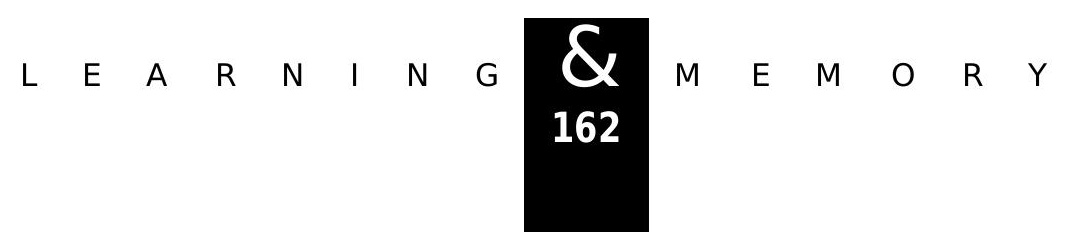


ies to mediate at least one type of learning in Drosophila.

Ablation of the mushroom bodies disrupts normal male habituation, although another dopaminemodulated behavior, female sexual receptivity, is unaffected by this treatment. Work by Tompkins and Hall (1983) has suggested that the focus for female receptivity resides within a group of cells in the dorsal anterior brain; some of the cell bodies within this region project their axons into the mushroom bodies. However, the data presented here suggest that dopaminergic modulation of female sexual receptivity does not require functional mushroom body tissue. Females become receptive to males after exposure to the male's courtship stimuli (Tompkins et al. 1982); female receptivity thus requires the processing of auditory and olfactory cues. How ever, sexual receptivity does not appear to require learning acquisition on the part of the female; thus, our results are consistent with previous data suggesting that the mushroom bodies mediate the processes of learning (de Belle and Heisenberg 1994; Connolly et al. 1996). Female sexual receptivity in mammals is apparently regulated by dopaminergic activation of specific steroid hormone receptors (Mani et al. 1994). Assuming that there are analogous hormone receptors in Drosophila activated by dopamine, which would be involved in the processing and integration of the male courtship stimuli, this signaling pathway likely resides outside the mushroom bodies.

O'Dell et al. (1995) have shown that perturbations within specific regions of the mushroom bodies alter mate discrimination in that males with feminized tissues court mature males as well as females. Dopamine-depleted males do not display this type of homosexual behavior (M. Walzer and W. Neckameyer, unpubl.), suggesting that the signaling pathways affecting mate discrimination are unlikely to be mediated by dopamine.

Ferveur et al. (1995) have also noted that flies feminized within either specific regions of the mushroom bodies or the antennal lobes direct courtship behavior to both mature males and females. Both these studies implicate these structures in the recognition of sex-specific pheromones and/or the control of sexually dimorphic courtship behaviors. Because hydroxyurea treatment does not appear to affect female sexual receptivity, it is unlikely that the focus for this behavior resides within the mushroom body or antennal lobe tissue affected by feminization. Ferveur has also proposed the possibility that ablation of the appropriate brain tissue may affect a male's ability to detect the anti-aphrodisiac pheromones produced by other mature males but not by immature males. Because dopamine-depleted males do not court mature males, another transmitter, and not dopamine, is responsible for modulating this behavior.

The association of given odors with shock is abolished when adenylate cyclase-mediated G protein signaling is perturbed specifically within the mushroom bodies (Connolly et al. 1996). Several Drosophila genes affecting olfactory learning show strong expression in this tissue (for review, see Davis 1993); these include rutabaga, which encodes a $\mathrm{Ca}^{2+}$ / calmodulin-sensitive adenylyl cyclase (Levin et al. 1992); DCO, a catalytic subunit of protein kinase A (Skoulakis et al. 1993); and dunce (Nighorn et al. 1991). Davis and colleagues have suggested a model for the dopaminergic modulation for olfactory conditioned learning in Drosophila that is mediated by adenylate cyclase (Han et al. 1996). Others have shown that the conditioned courtship associative learning mediated by the $\mathrm{Ca}^{2+} /$ calmodulin-dependent protein kinase type II requires a visual input (Joiner and Griffith 1997). Clearly, learning processes in Drosophila can occur via several mechanisms and sensory modalities. We propose that dopamine initiates a signaling cascade in the habituative experience-dependent modification of behavior that utilizes at least some of these pathway components.

\section{Acknowledgments}

I gratefully acknowledge the suggestions of Dr. Martin Heisenberg, the critical comments and advice of Dr. Laurie Tompkins, and the assistance with statistical analysis by Andriana Villella. This work was supported by National Science Foundation (NSF) grant no. IBN-9423616 to W.S.N. The publication costs of this article were defrayed in part by payment of page charges. This article must therefore be hereby marked "advertisement" in accordance with 18 USC section 1734 solely to indicate this fact.

\section{References}

Budnik, V. and K. White. 1988. Catecholamine-containing neurons in Drosophila melanogaster. Distribution and development. J. Comp. Neurol. 268: 400-413.

Civelli, O., J. Bunzow, and D. Grandy. 1993. Molecular diversity of the dopamine receptors. Annu. Rev. Pharmacol. Toxicol. 33: 281-307.

Connolly, J., I. Roberts, J. Armstrong, K. Kaiser, M. Forte, T. Tully, and C. O'Kane. 1996. Associative learning disrupted

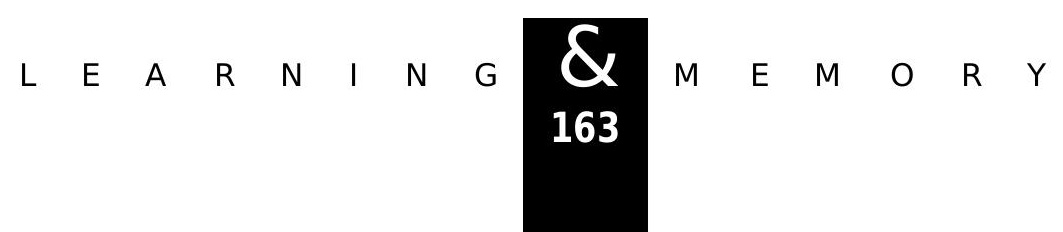




\section{Neckameyer}

by impaired Gs signaling in Drosophila mushroom bodies. Science 274: 2104-2107.

Davis, R. 1993. Mushroom bodies and Drosophila learning. Neuron 11: 1-14.

de Belle, S. and M. Heisenberg. 1994. Associative odor learning in Drosophila abolished by chemical ablation of mushroom bodies. Science 263: 692-695.

- - . 1996. Expression of Drosophila mushroom body mutations in alternative genetic backgrounds: A case study of the mushroom body miniature gene $(\mathrm{mbm})$. Proc. Natl. Acad. Sci. 93: 9875-9880.

Feng, G., F. Hannan, V. Reale, Y. Hon, C. Kousky, P. Evans, and L. Hall. 1996. Cloning and functional characterization of a novel dopamine receptor from Drosophila melanogaster. J. Neurosci. 16: 3925-3933.

Ferveur, J.-F., K. Stortkuhl, R. Stocker, and R. Greenspan. 1995. Genetic feminization of brains sructures and changed sexual orientation in male Drosophila. Science

267: 902-905.

Gailey, D., F. Jackson, and R. Siegel. 1982. Male courtship in Drosophila: The conditioned response to immature males and its genetic control. Genetics 102: 771-782.

Gailey, D., R. Lacaillade, and J. Hall. 1986. Chemosensory elements of courtship in normal and mutant olfaction deficient Drosophila melanogaster. Behav. Genet. 16: 375-405.

Goldstein, M. and A. Deutch. 1992. Dopaminergic mechanisms in the pathogenesis of schizophrenia. FASEB J. 6: 2413-2421.

Greenspan, R. 1995. Understanding the genetic construction of behavior. Sci. Am. 272: 72-78.

Han, K., N. Millar, M. Groteweil, and R. Davis. 1996. DAMB, a novel dopamine receptor expressed specifically in Drosophila mushroom bodies. Neuron 16: 1127-1135.

Hornykiewicz, O. 1966. Dopamine and brain function. Pharmacol. Rev. 18: 925-964.

Jackson, D. and A. W estlind-Danielsson. 1994. Dopamine receptors: Molecular biology, biochemistry and behavioral aspects. J. Pharmacol. Exp. Ther. 64: 291-369.

Joiner, M. and L. Griffith. 1997. CaM kinase II and visual input modulate memory formation in the neuronal circuit controlling courtship conditioning. J. Neurosci.

17: $9384-9391$.

Levin, L., P. Han, P. Hwang, P. Feinstein, R. Davis, and R. Reed. 1992. The Drosophila learning and memory gene rutabaga encodes a $\mathrm{Ca}^{2+} /$ calmodulin-responsive adenylyl cyclase. Cell 68: 479-489.

Mani, S., J. Allen, J. Clark, J. Blaustein, and B. O'Malley.
1994. Modulation of the ligand independent activation of the human estrogen receptor by hormone and anti-hormone. Science 265: 1246-1250.

Nassel, D. and K. Elekes. 1992. Aminergic neurons in the brain of blowflies and Drosophila: Dopamine- and tyrosine-hydroxylase-immunoreactive neurons and their relationship with putative histaminergic neurons. Cell Tiss. Res. 267: 147-167.

Neckameyer, W. 1996. Multiple roles for dopamine in Drosophila development. Dev. Biol. 176: 209-219.

- - - 1998. Dopamine modulates female sexual receptivity in Drosophila melanogaster. J. Neurogenet. (in press).

Neckameyer, W. and W. Q uinn. 1989. Isolation and characterization of the gene for Drosophila tyrosine hydroxylase. Neuron 2: 1167-1175.

Neckameyer, W. and K. White. 1993. Drosophila tyrosine hydroxylase is encoded by the ple locus. J. Neurogenet. 8: 189-199.

O 'Dell, K., J. Armstrong, M. Yang, and K. Kaiser. 1995. Functional dissection of the Drosophila mushroom bodies by selective feminization of genetically defined subcompartments. Neuron 15: 55-61.

Roebertson, H.M., C.R. Preston, R.W. Phillis, D.M. Johnson-Schlitz, W.K. Benz, and W.R. Engels. 1988. A stable genomic source of $\mathrm{P}$ element transposase in Drosophila melanogaster. Genetics 118: 461-470.

Rubin, G. and A. Spradling. 1982. Genetic transformation of Drosophila with transposable element vectors. Science 218: 348-352.

Sawaguci, T. and P. Goldman-Rakic. 1994. The role of D1-dopamine receptor in working memory: Local injections of dopamine antagonists into the prefontal cortex of rhesus monkeys performing an oculomotor delayed-response task. J. Neurophysiol. 71: 515-528.

Seeman, P., H. Guan, and H. Van Tol. 1993. Dopamine $D_{4}$ receptors elevated in schizophrenia. Nature 365: 441-445.

Siegel, R. and J. Hall. 1979. Conditioned responses in courtship behavior of normal and mutant Drosophila. Proc. Natl. Acad. Sci. 76: 3430-3434.

Skoulakis, E., D. Kalderon, and R. Davis. 1993. Preferential expression in mushroom bodies of the catalytic subunit of protein kinase $A$ and its role in learning and memory. Neuron 11: 197-208.

Sokal, R. and F. Rohlf. 1995. Biometry, Ed. 3. W.H. Freeman and Co., New York, NY.

Stocker, R., G. Heimbeck, N. Gendre, and S. de Belle. 1997. Neuroblast ablation in Drosophila p[Gal4] lines reveals origins of antennal target interneurons. J. Neurobiol. 32: 443-456.

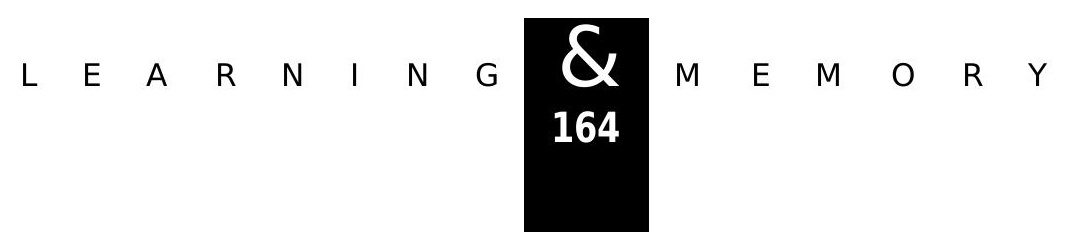


Tempel, B., M. Livingstone, and W. Q uinn. 1984. Mutations in the dopa decarboxylase gene affect learning in Drosophila. Proc. Natl. Acad. Sci. 81: 3577-3581.

Tompkins, L. 1989. Homosexual courtship in Drosophila. In Perspectives in neural systems and behavior, pp. 229-248. Alan R. Liss, New York, NY.

Tompkins, L. and J. Hall. 1983. Identification of the brain site controlling female receptivity in mosaics of Drosophila melanogaster. Genetics 103: 179-195.

Tompkins, L., A. Gross, J. Hall, D. Gailey, and R. Siegel. 1982. The role of female movement in the sexual behavior of Drosophila melanogaster. Behav. Genet. 12: 295-307.

Vaias, L., L. Napolitano, and L. Tompkins. 1993. Identification of stimuli that mediate experience-dependent modification of homosexual courtship in Drosophila melanogaster. Behav. Genet. 23: 91-97.

Yin, J., J. Wallach, M. Del Veccio, E. Wilder, H. Zhou, W. Q uinn, and T. Tully. 1994. Induction of a dominant-negative CREB transgene specifically blocks long-term memory in Drosophila. Cell 79: 49-58.

Received December 17, 1997; accepted in revised form April 14, 1998. 


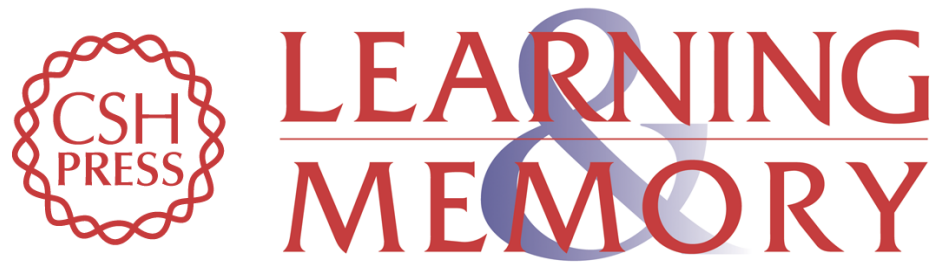

\section{Dopamine and Mushroom Bodies in Drosophila: Experience-Dependent and -Independent Aspects of Sexual Behavior}

Wendi S. Neckameyer

Learn. Mem. 1998, 5:

Access the most recent version at doi:10.1101//m.5.1.157

References This article cites 34 articles, 14 of which can be accessed free at: http://learnmem.cshlp.org/content/5/1/157.full.html\#ref-list-1

License

Email Alerting

Receive free email alerts when new articles cite this article - sign up in the box at the Service top right corner of the article or click here. 